\title{
UNDERSTANDING EXTERNAL RELATIONS OF FEDERATED UNITS AND REGIONS
}

Keywords:

Paradiplomacy; Diplomacy; Substate actors; Federalism; Federated units; Regions; International relations; Diplomatic tools; Nationalism; Separatism; International organisations;

Author:

Dr. Nina Sajić is a Research Fellow at the Conflict Analysis Research Centre (CARC) at the School of Politics and International Relations, Univeristy of Kent, England, UK.

Correspondence: nsajic@yahoo.com

Field:

International relations

\begin{abstract}
This paper examines in detail the major themes that have emerged in the academic study of external relations of substate entities. It begins by exploring definitions of the external relations and international activities of federated units and regions and presents a brief history of when and how sub-state units emerged at the international scene; in other words, it considers the groundwork for their international presence and displays how changes in international relations create room for new actors. The paper then considers why federated units and regions engage in external relations, including their motivations, incentives, and strategies. The paper also examines the role of nationalism and separatism in the international activities of federated units and regions, how central authorities react, and what measures they may take against their sub-state units. The participation of regions and federated units in international organisations is also analysed here.
\end{abstract}

\subsection{7/politeia0-24348}

Paper received on:

03.10 .2019

Paper accepted for publishing on: 


\section{INTRODUCTION}

Over the last couple of decades, many sub-state actors have been trying to influence decisions outside their national borders. With the increasing number of international governmental and non-governmental organisations and interest groups, the development of modern technologies, and the globalisation of markets, economy, trade, and investments, a space has opened for new actors in world politics, one in which central state authorities no longer have exclusive monopoly over external relations.

The international activities of federated units and other non-central actors, such as regions, provinces, cantons and cities, have been given a number of different names. Scholars often use paradiplomacy to denote international activities of federated units and regions, but other terms, such as constituent diplomacy, regional micro-diplomacy, global micro-diplomacy, catalytic/ multi-layered diplomacy, regional sub-state diplomacy, postdiplomacy, protodiplomacy etc., appear in the literature as well. There are also those (Melissen 1998), who suggest that the international activities of all actors, regions and federated units included, should simply fall under the category of diplomacy. ${ }^{1}$

International activities of sub-state actors were subject to some sporadic academic analysis as early as the 1970s. In 1970, Atkey wrote about the role of Canadian provinces in international affairs and how and to what extent provincial international activities could be accommodated within Canadian foreign policy. He does not try to define attempts by Canadian provinces to project themselves internationally; he simply men-

1 Melissen defines diplomacy as a "mechanism of representation, communication and negotiation through which states and other international actors conduct their businesses." (Melissen, 1998: xvii) tions "international activities and initiatives" and suggests Ottawa should neither ignore their existence nor portray them as illegal under constitutional and international law (Atkey, 1970: 269).

The term "paradiplomacy" appeared in the literature even in the 1960s to denote diplomatic activities parallel to those of traditional official diplomacy, often called "secret diplomacy.” For example, Butler defined paradiplomacy as "the highest level of personal and parallel diplomacy, complementing or competing with the regular foreign policy of the minister concerned, is thus a recurrent temptation to the chief of the executive, be he a premier or president, dictator or monarch" (Butler, 1961: 13). The context that Butler gives here to the term has little to do with international activities of federated units and regions; it refers to backdoor diplomacy or clandestine diplomatic practices of states in some crisis situations. ${ }^{2}$ Such employment of the term can make the use of "paradiplomacy" controversial as rightly pointed by Cornago (2013).

One of the first attempts to come up with a neologism to define international activities of federated units and regions appears in a special issue of Publius: Journal of Federalism in 1984. In this special issue, Duchacek (1984) identifies two types of paradiplomacy: transborder regional regimes and "global micro-diplomacy.” Trans-border regionalism refers to formal and informal interactions of neighbouring subnational units across borders; according to Duchacek, this type of cooperation dates back to the Peace of Westphalia. Global micro-diplomacy entails international activities of subnational actors that go far beyond their immediate neighbourhood. Duchacek (1990) develops further these two concepts in his later work by pro-

2 See for example Jones and Petersen (2013). 
viding a typology of paradiplomacy based on its geopolitical dimension: trans-border regional paradiplomacy (essentially the same as his previous definition of trans-border regionalism), trans-regional paradiplomacy (interaction and cooperation between regions that are not neighbours but their countries are) and global paradiplomacy (the same as global micro-diplomacy). In addition to the geopolitical dimension, Duchacek adds a type of international activity that is motivated by separatist aspirations and ambitions and calls it protodiplomacy. Duchacek is not consistent in his use of the terms, however, and has been criticised by some scholars for confusing "paradiplomacy" and "microdiplomacy."

Attempting to avoid terminological controversies, Cornago proposes the following definition: "paradiplomacy can be defined as non-central governments' involvement in international relations through the establishment of permanent or ad hoc contacts with foreign public or private entities, with the aim to promote socioeconomic or cultural issues, as well as any other foreign dimension of their constitutional competencies" (Cornago, 1999: 40). Although this definition entails the most important characteristics of the development of the international agency of sub-state units, the discussion revolves here not around how to describe international activities, but how to name them. The use of the term paradiplomacy has been contested by some scholars (e.g. Hocking, Kincaid etc.) simply because the term is suggestive of a second-order set of activities. Hocking also argues that terms such as paradiplomacy or protodiplomacy "reinforce the distinction" and "emphasise the elements of conflict between the national and subnational governments" (Hocking, 1993: 3-4).

Vocabulary that is used to describe international activities of federated units and regions is far from being unified. There have been many attempts to come up with a terminology that is neither derogatory nor suggestive of inferiority. For example, Kincaid (1990) proposes a "constituent diplomacy" as a term that could be a neutral descriptor. Postdiplomacy or beyond diplomacy is another neologism used to label the international activities of federated units; it is described as a "process that moves beyond the nation state" (Aguirre, 1999: 205). Hocking's concept, known as multi-layered or catalytic diplomacy, regards external relations of federated units and regions "not as a segmented process presided over by undisputed gatekeepers, but a web of interactions with a changing cast of players interacting in a variety of contexts depending on policy issues, interests and the capacity of actors to operate in a multilevel political milieu that transcends conventional distinctions between subnational, national and international arenas" (Hocking, 1993: 36).

Hocking's concept of multilayered diplomacy is favoured over paradiplomacy by some scholars. For example, in his analysis of international activities of German provinces and US states, Kaiser (2005) argues that because of regional trade initiatives such as NAFTA and regional integration processes such as the EU, paradiplomacy, which presupposes the separation of foreign and domestic policies, is decreasing in favour of multilayered diplomacy, which deals with coordinated measures and policy making across borders or different territorial levels.

In a special issue of The Hague Journal of Diplomacy on "Regional Sub-state Diplomacy Today," (2010) Cornago, Criekemans and others use the term sub-state diplomacy to refer to international activities of non-central governments. Cornago says sub-state diplomacy is more appropriate to explain "a reality that is becoming commonplace in the daily 
policy-making processes of many local and regional governments throughout the world and is increasingly accepted by the diplomatic system itself" (Cornago, 2010: 13). However, sub-state diplomacy can easily be seen as a derogatory term.

As the purpose of this Article is not to provide another neologism that could risk rejection or contestation or simply contribute to existing terminological confusion, the Article proposes the use of more neutral terms that have neither inferior nor secondary connotations. Terms "international activities" and "external relations" are used interchangeably in this Article to describe relations of federated units and regions with foreign governments, federated units, international governmental organisations and other foreign entities and denote their participation and involvement in international relations whether of an ad hoc or permanent nature.

\section{HOW AND WHEN IT ALL STARTED}

Although the academic study of the external relations of federated units and regions began in the 1980s, the international presence of sub-state units is not a new phenomenon. Today, states share the international stage with sub-state actors, just in the same way as they "share(d) the stage with other associations: during the mediaeval times" (Bull, 1977: 254). Trans-border regional and neighbourhood cooperation and linkages are "probably as old as humanity itself" (Duchacek, 1990: 23). The roots of traditional state-centric diplomacy go back to the ancient times and can be found in different practices of public and private communications among various political entities (Cornago, 1999). In Mediaeval times, non-sovereign entities were involved in diplomatic activities, including sending and receiving envoys, con- ducting negotiations and concluding agreements (Cohen, 1998). The 1848 constitution of Switzerland provided for its sub-state units to have international relations; accordingly, Switzerland spoke with the "twenty six voices of the confederation and the twenty five cantons" (Thürer, 2003: 28). In the relatively recent history of international relations, some sporadic international activities of the Basques at the end of the $19^{\text {th }}$ and the start of the $20^{\text {th }}$ century can be traced. ${ }^{3}$ At the beginning of the $20^{\text {th }}$ century, Quebec had missions in Paris, London, New York and Brussels, and certain American states and their governors participated in international activities in the 1950s and 1960s.

Thus, although Bull says we are seeing the emergence of a "neo-mediaeval form of universal political order" (Bull, 1977: 255), what we are witnessing is not so much the revival of an old phenomenon as the expansion of an ongoing one. So it could be argued that diplomacy actually underwent different stages of historical development before the Westphalian system of states tried to attribute it exclusively to the domain of nation states (Cornago, 1999). In any event, in today's world, nation states are often multivocal or polyphonic actors, with federated units or regions, interest groups or ethnic communities acting on the international scene (Aguirre, 1999). Or as Keating puts it:

"We are in a world where multiple spheres of authority coexist with multiple systems of action. It would be a serious error to present this as totally new, or to contrast it with a mythical state of the classical era, which was able to monopolise authority and internalise the policy process. These tendencies have always been present, but have been greatly magnified in the contemporary era and affect

3 See Zubiri (1999). 
most seriously those states, which in the past have sought to centralise and monopolise authority" (Keating, 2000: 31).

While formal and informal interactions of sub-state units with neighbouring communities, regions and states is not new, what is new, according to Duchacek (1984), is the intensity and political impact and complexity of their interaction with the world. Soldatos (1990) adds that the novelty of the plurality of the international actors lies in its manifestation in qualitative and quantitative terms. By qualitative terms Soldatos means activities of sub-state actors are direct and relatively autonomous, and by quantitative, that activities of federated units and regions are increasingly wide in scope.

The recent burgeoning of international agency is the topic of some discussion in the literature on the external relations of sub-state units. Arguments include internationalisation of domestic issues, economic globalisation, democratisation, human rights, decentralisation, federalisation, devolution, regionalisation, the rise of nationalism, the EU integration and US. There is an on-going debate as to whether traditional state foreign policy is expanding or domestic and internal issues are internationalising. Lecours (2002a) says the international actorness of federated units and regions is the result of changes both at the domestic and the international level.

At the former, important changes include the rise of nationalism and the processes of decentralisation and devolution now occurring in some countries such as for example in the UK. Others factors include conflict or tensions with central authorities that can also trigger internationalisation of federated units and regions. For example, Feldman and Feldman (1984) argue that the conflict with Ottawa accounts for much of Quebec's international activities. At the latter level, economic globalisation and the creation of supra-national institutions have had a significant impact on the internationalisation of sub-national entities.

However, separating international from domestic is problematic and it does not reflect as Habegger (2003) rightly points out, today's political realities. The internationalisation of internal issues has led to what Hocking (1993) calls “localisation of foreign policy." Rosenau (1997) further develops Hocking's idea of localisation of foreign policy and suggests the boundaries between domestic and foreign affairs are diminishing, creating a political space that he calls "frontiers;" the boundaries "have been eroded and become porous, being transgressed by a variety of diverse types of actors and issues" (Rosenau, 1997: 32).

Many scholars use globalisation to explain the changing international arena. According to Lecours, paradiplomacy is a manifestation of globalisation; regions and federated units become part of globalisation rather than simply "being acted upon by its processes" (Lecours, 2003:1). Vengroff and Rich (2006) argue globalisation has had a huge impact on the international activities of Canadian provinces; they are heavily dependent on international trade, making global competitiveness a critical component of their motivation to act internationally. According to Telford as a result of globalisation, "contemporary political problems do not fit neatly into distinct jurisdictional boundaries, if they ever did" (Telford, 2003: 3) creating a rather complex network of international relationships. On the other hand, Kincaid (2003) claims globalisation itself did not make as large a contribution to the internationalisation of federated states and regions as is generally understood. During the first era of modern globalisation in the late $19^{\text {th }}$ century, there was a virtual absence of what he calls constit- 
uent diplomacy. In his view, globalisation is as much a context for constituent diplomacy as it is a cause. Other factors, such as democratisation, inter-governmentalisation, human rights, decentralisation, market liberalisation, United States policies, and technological innovation in travel and communications, were highly interdependent by the 1980s, setting the scene for a new phase of globalisation, considerably different than the one of the XIX century.

Paquin and Lachapelle (2005) list three variables at the forefront of the expansion of the international presence of federated units and regions: the nation-state crisis and globalisation, nationalism and the internationalisation process. They argue that "international reorganisation at the economic level has led to a new division of labour" (Paquin and Lachapelle, 2005: 78) creating room for other actors who are not nation states to compete for the acquisition of shares in world markets. A case in point would be the participation of US states and Canadian provinces on the international arena. The American states have always been interested in foreign affairs and "have from time to time throughout American history, exerted considerable political influence" (Vile, 1961: 194). One of the first international activities of US states can be traced back to 1959 when a delegation from North Carolina led by Governor Luther H. Hodges travelled to Europe to attract foreign investments. Despite the early beginning, throughout the 1960s and 1970s, timid and underdeveloped; for example, in the 1970s only four US states were represented abroad. The 1980s saw the beginning of an increased international presence with more governors traveling on trade missions, and more states launching campaigns or opening more trade representative offices abroad; in 1985, 29 states had 55 international offices and today over 40 states have roughly 250 representations abroad. Fry (1990a) cites six reasons for the increased international activity of US states: complex global interdependence, the growing dependence of the US on the global economy; electoral factors (the international presence of leaders plays an important role in the electoral campaign); a desire to decrease state reliance on transfer payments from Washington (states want to decrease their reliance on Washington and look for alternatives to federal funding); the development of transport and communication accompanied by the internationalisation of production; constitutional ambiguity. Although Fry is referring to US states, these factors can be applied to elsewhere as well.

For many scholars (Bullman, 1996; Kerremans and Beyers, 1996; Aldecoa, 1999; Borzel, 2000 etc.), European integration has been the driving force in the development of the international agency of federated units and regions. With the acceleration of the European integration, especially with the adoption of the European Act in 1986 and the Maastricht Treaty in 1992, the importance of regions and federated units on the international scene has increased. For example, in the case of Belgium, EU integration coupled, with Belgian state reforms, has blurred the boundaries between what Kerremans and Beyers (1996) call second level player (nationstates) and third level player (sub-national units). Marks, Haesly, and Mbaye (2002) see EU integration both as an opportunity and a threat for regions and federated units, especi ally those who exert considerable influence on their national polities. Regions and federated units who try to influence EU policy can gain simply because many EU polices are within their jurisdiction. Those who do not try to influence EU policies have more 
to lose "because if they are unable to operate effectively in Europe they face the prospect of being outflanked by national governments" (Marks, Haesly, and Mbaye, 2002: 9).

For Lecours (2002b), political and economic regimes are crucial elements of the institutional context conditioning the international activities of federated units. Political supra-national structures such as the EU legitimise bypassing the central state institutions; in the EU, many regions and federated units "have found specific institutional niches such as the Council of regions" (Lecours, 2002b: 3 ), that they use to exert their influence. The Council of regions, regardless of its flaws, is important, as Loughlin explains: "For the first time, regions and local authorities are officially represented in their own European body and not simply as an appendage to the Commission or the Parliament. This means that there is now official recognition of the sub-national territories alongside the recognition of national territories as found in the Council of Ministers" (Loughlin, 1996: 163).

It is important to note here that the German Länders and the Belgian Communities and Regions mobilised to change the system of the representation at the EU, by which only the national ministers may take part in a decision-making process and vote. This resulted in the revision of the 142 EEC Article to the 203 TEU Article in 1992, allowing the ministers of federated units to participate actively in the EU Council of Ministers, but under the condition that they represent not the interest of their respective regions or communities, but the interests of the federation as a whole. ${ }^{4}$ Notwithstanding the influence of EU integration, the increased international action by sub-state units cannot be attributed to one factor, or one set of interconnected factors. As presented briefly here, numerous

4 See Beyers and Bursens (2009). external and internal conditions have made it possible. Sykes and Shaw (2007) say the new regionalism, as they call it, has not been driven just by external factors such as globalisation and European integration; other longstanding issues, such as national identity, political domination by the centre and economic disparities, have to be taken into account as well.

\section{MOTIVATIONS AND INCENTIVES}

When analysing the external relations of federated units and regions, one of the first questions that comes to mind is why do they do it. What are their motivations, and what are they trying to achieve internationally? Vengroff and Rich (2006) say global competitiveness is a critical component of the motivation for a federated unit or a region to project itself internationally. For Atkey (1970), the internationalisation of federated units and regions is more convenient and practical than having to follow the lead of a level of government that is not "as closely attuned" to their needs. According to Feldman and Feldman (1984), federated units and regions participate on the international scene for both internal and external reasons. Internal reasons include bureaucratic and fiscal resources, formal opportunities, jurisdictional obligations or the political necessity to engage in international relations. External reasons may be found in the international system itself, which encourage them to engage internationally; for example, foreign countries and other partners for various reasons may approach them directly.

Scholars in the field (Keating, 1999; Kincaid, 2003; Blatter et al., 2008) tend to agree on three broad motivations: economic (e.g. trade, export, investments), cultural (e.g. cultural exchanges, promotion of distinct cul- 
ture, identity building, recognition of cultural distinctiveness) and political (e.g. protection of autonomy, internal status, region building, nationalist aspiration, independence seeking, recognition of political autonomy). To the political motivations, Kincaid (2003) adds the protection of human rights and the environment. A fourth motivation added by Kincaid is cross-border housekeeping; this stems from the need to resolve numerous cross-border issues.

According to Feldman and Feldman (1990), a desire for independence or special federal assistance can also motivate federated units and regions to move into the international sphere. They may also decide to pursue their own external relations because of the central government's lack of action in a certain area or its refusal to create policy on certain issues. Fry (1990b) calls this motivation a "controversial moral stance;" strong views on a moral issue can lead to controversial decisions by federated units and regions to enter the international arena. Consider, for example, the temporary embargo on the sale of alcohol from the USSR introduced by 15 US states following the shooting down of a KAL airplane by the USSR in 1983. Another example is environmental protection, often seen by federated units and regions, especially in the developed world, as an important moral issue. Among the first to be concerned with the protection of the environment are US states and Canadian provinces. The issue of climate change was discussed for the first time at the annual Conference of New England Governors and East Canadian Premiers (NEG-ECP) in 1989; in the years that followed NEC-ECP began to develop expertise in climate change. ${ }^{5}$ In the absence of formal ratification of the Kyoto Protocol by the US, several states began to take their own initiatives, even though they

5 See Chaloux and Paquin (2012). were not party to the formal Protocol. Nine states created the Regional Greenhouse Gas Initiative (RGGI) as a market-based trading programme to reduce greenhouse gas emissions. ${ }^{6}$ In 2006, the Governor of California signed the Global Warming Solution Act, which provides for cutting back greenhouse gas emissions by 25 per cent by 2020 . The absence of action by Washington and Ottawa in climate change "has had an antagonistic effect on states and provinces" (Chaloux and Paquin, 2012: 221), but has created a window of opportunity for them to develop their own policies and increase their roles in environmental protection. In 2017, the Governor of California met with the President of China and signed an agreement to reduce greenhouse gas emission, only a week after the US President announced the withdrawal of the US from the Paris climate agreement. These climate change initiatives have been called green or environmental paradiplomacy. The concept of environmental paradiplomacy is relatively new but is likely to gain prominence in the future.

\section{IDENTITY AND NATIONAL QUESTIONS}

Pressures from human rights movements and groups opened the door not only for individuals, but also for ethnic, religious, and linguistic communities, especially stateless nations, to assert their rights as "distinct societies deserving recognition, self-government, and distinctive voices in national and international affairs" (Kincaid, 2003: 76). For many territories with distinctive identities, international activities have become integral parts of their identity and nation building. Put otherwise, the development of international agency

6 See Regional Greenhouse Gas Initiative https:// www.rggi.org (accessed 10 ${ }^{\text {th }}$ October, 2019). 
is an "indispensable priority" for federated units and regions that want their identities to be recognised and legitimised both domestically and on the international level (Paquin and Lachapelle, 2005).

The importance of the nationalism dimension in the development of international practices of sub-state units is analysed extensively by Lecours and Moreno. These two scholars say nationalism "logically leads regional governments to seek international agency" and the international presence of federated units and regions "is likely a consequence of the existence of a strong nationalist movement" (Lecours and Moreno, 2001: 2). Nationalism, in their view, includes three processes whose underlying philosophy and practice can be directly associated with the development of international agency of federated units and regions: identity construction and consolidation, the definition and articulation of regional/group interests, and political-territorial mobilisation. As for the first process, they argue that for nationalist leaders of federated units and regions, an international presence is an additional opportunity to build and consolidate a national identity; while conducting their external relations, federated units and regions can behave as nations and present themselves as such. They link the development of international agency of federated units and regions to the second process of nationalism, as sub-state units adopt a "state-like discourse... and express preferences in the context of a national interest framework" (Lecours and Moreno, 2001: 2). These preferences and interests may be ideological in nature, such as free trade, or involve culture defence and promotion, and often are the most important issues of external relations of federated units and regions. As a result, the struggle to preserve culture domestically is extended internationally through the international activities of federated units and regions with a distinctive identity. Their international activities are also linked with the third dimension of nationalism; they provide opportunities to "stimulate political-territorial mobilisation" (Lecours and Moreno, 2001: 5), as they often challenge central authorities and can serve as a tool to achieve some objectives domestically.

In an analysis of sustainable development policies of five sub-state units, Happaerts (2012) concludes the degree of autonomy is not directly linked to the significance of international influence; rather, the presence of territorial identities explains why Flanders is more influenced by international developments than Wallonia. Although the development of international agency by federated units and regions seeking to advance their cultural and political objectives internationally as national states represents the most conflictual dimension of their external relations, Kincaid says it is very likely to increase in the near future, because many "assertions in the names of human rights and cultural diversity are occurring worldwide" (Kincaid, 2003: 92).

\section{REACTIONS FROM THE STATES}

States react differently to the development of international agency of their federated units and regions. Some reactions are very favourable, with the internationalisation of federated units and regions seen as "desirable democratisation of foreign policy process" (Hocking, 1993b: 2) and an opportunity to make the international arena more just and peaceful. Others are negative. Many multinational states believe the international projection of federated units and regions is a "dangerous derogation from governments" power to conduct a coherent foreign policy" 
(Hocking, 1993b: 2). International activities are often seen by nation-states as their exclusive privilege, the "area that touches most closely the traditional concept of national sovereignty (Loughlin, 2000: 29). Although Kincaid (1990) says this notion that politics "stops at the water's edge" goes against the basic principles of democratic governing, Atkey (1970) argues the external relations of federated units and regions should be supervised in such a way that they not damage the national interest of their states.

According to Lecours, states perceive the international activities of their sub-units as a challenge to sovereignty and an obstacle to "the articulation of a coherent national foreign policy" (Lecours, 2002s: 4). But Kincaid (2003) argues that we should not worry whether the diplomatic activities of sub-state actors will endanger sovereignty; rather, we should consider how the suppression and control of the international presence of federated units and regions could endanger democracy in a state and limit the political, cultural and economic potential of sub-state units. Atkey also says direct state control might hinder valuable programmes and initiatives undertaken by provincial and foreign officials, thus "emphasising form at the expense of substance" (Atkey, 1970: 252).

The growing international role and importance of federated units and regions does not mean, however, that we are witnessing the disappearance of nation-states. As many of the tasks of nation-states have been taken over by supra-national institutions such as the EU or NATO or transferred to decentralised structures, their nature, their role - both internally and externally - and their function has been changing (Loughlin, 2000). The international activities of regions are far from challenging the dominant role of the nationstate and its executive branch in political decision-making. To cite Roseneau:

"[The international system is] less commanding, but is still powerful, states are changing, but not disappearing, state sovereignty has been eroded, but is still vigorously asserted, governments are weaker, but they can still throw their weight around, frontiers are continuously shifting, widening and narrowing, simultaneously undergoing erosion with respect to many issues and reinforcement with respect to others." (Rosenau, 1997: 4)

Some nation-states have started to realise the importance of their sub-state units and this recognition has led to a greater appreciation of their international roles and their influence on foreign policy outcomes. Management of global issues, especially in crises, according to Langhorne, increasingly involves other actors that are not states and which have "levels of efficiency and responsiveness that transcend the constraints of the state" (Langhorne, 2005: 332). Although Langhorne is referring to private corporations, non-governmental and governmental organisations, central governments can benefit from the external relations of their federated units and regions. For example, Hocking (1993) believes that by engaging the services of sub-state actors, sensitive political issues can be redefined in lower level politics.

Certain forms of international activities of sub-state units can be used as an instrument to reduce transnational tensions. According to Cornago (1999), this is shown most clearly in the management of environmental and migration issues, where the action of central or federal authorities has not been sufficient, as briefly discussed above. There are many examples where sub-states have been involved in solving international issues, especially related to environment protection, such as the joint international action of several fed- 
erated units of Canada and the US against the ecological deterioration of their regional ecosystems.

Nonetheless, some states, especially multinational ones, find it difficult to appreciate the international role of their domestic actors or to accept the international presence of their federated units. Lecours (2002a) says they can oppose it vigorously, taking drastic measures to suspend activities of the sub-state units, such as legal procedures, or more moderate ones, such as diplomatic activities aimed at bilateral partners with whom the sub-state units are developing cooperation. There are many examples of states invoking the constitution to ban the international relations of their federated units or regions. For example, Spain contested the international activities of its autonomous communities before the Constitutional Court by submitting an appeal against the Basque Government with respect to its office in Brussels. In 1994 the Constitutional Court confirmed the right of the Basque government to be officially represented in Brussels. A similar case occurred in Bosnia and Herzegovina; the Bosniak member of the Presidency of Bosnia and Herzegovina submitted an appeal to the Constitutional Court in 2008 to suspend "anti-constitutional" activities of the Republika Srpska in the US, but the Constitutional Court of Bosnia and Herzegovina rejected the appeal.

Such attempts are counterproductive for at least two reasons: they can worsen the relations between the centre and the federated unit and they can obstruct the governance of a federated unit. Some suggest that tensions and conflicts arising from the international projection of federated units and regions are determined by the internal political or ethnic composition of states, intergovernmental relations and the nature of international activities in which sub-states are involved.
Intergovernmental conflict is more likely to occur in multinational and multi-ethnic countries, such as for example Canada, Bosnia and Herzegovina, Spain, the UK, where the development of the international agency of their federated units and regions is often motivated by the expression of their cultural, ethnic and political distinctiveness. Kincaid (2003) claims the international projection of sub-state units itself is seldom the cause of intergovernmental conflict. Tensions arising because of the external relations of substate units usually reflect an already existing domestic intergovernmental conflict. In such cases, attempts to suspend the international activities of sub-state units will serve no purpose.

Whether federal or central governments try to prohibit international activities of their federated units and regions or provoke them depends on whether intergovernmental relations are antagonistic or cooperative (Feldman and Feldman, 1984). The centre may allow its constituent parts to play an international role as long as this does not threaten its interests and the image it wishes to project abroad (Balthazar, 1999). According to Atkey (1970), federal or central governments should not object to the development of the international agency of their federated units and regions as long as there is a full and honest disclosure of their international activities and as long as those activities do not jeopardise national interests.

Kincaid (2010) argues that the international activities of federated units and regions driven by some form of national aspirations may also produce conflict within that sub-national unit, as not all of its citizens may be supportive. Duchacek (1984) lists seven sources of opposition from central authorities: opposition in principle to any dilution of central power (invoking the constitution); fear of 
change; fear of new and complex patterns; inexperience and lack of negotiating skills of personnel of federated units and regions engaged in external relations; fear of creating political and administrative chaos; fear of "subnational egocentrism" (interests promoted by one federated unit or region to the detriment of another); and fear of secession. Notwithstanding these and other concerns, in most cases, the international projection of federated units and regions does not contravene national foreign policy objectives; in fact, it often complements them.

However, how and to what extent can external relations of sub-state units co-exist with those of the state? There are two possible scenarios Soldatos (1990) calls "cooperative (supportive) action" and "parallel (substitute) action." In cooperative action, the involvement of federated units and regions on the international arena is either coordinated by their central authorities or developed together with them. Parallel action refers to independent international involvement by federated units and regions, either in harmony or disharmony with central authorities.

Building on Soldatos' argument, Tatham (2010) develops two types of external relations: "bypassing paradiplomacy" and "co-operative paradiplomacy." The former can be defined as international activities of substate units that do not involve interactions with the central state, while the latter are conducted "in tandem" with the central state. For whatever reasons, federated units and regions may prefer to use their own mechanisms for external relations, especially in cases of what Tatham calls "bypassing paradiplomacy." In some cases, the state-centric networks and mechanisms of traditional diplomacy may be closed to federated units and regions. They may have no choice, but to create their own strategies.
In their analysis of the international activities of four Canadian provinces (Quebec, Alberta, Ontario and British Columbia) Feldman and Feldman (1984) argue that strategies of these provinces differ even when their purposes are the same. Strategies reflect the relations the respective units have with the centre, so for example, Quebec has, especially in the past, deliberately challenged the government of Canada, especially in the francophone world. But even in the case of cooperative paradiplomacy, where federated units and regions can rely on state-centric diplomatic mechanisms, they may still decide to develop their own instruments and networks. For example, American states, whose international activities are generally cooperative vis-à-vis their federal authorities, have developed extensive networks of around 300 offices in the world.

\section{HOW THEY DO IT}

Whether federated units and regions bypass or cooperate with their central authorities, they have some common instruments and mechanisms, all of which have become more sophisticated over time. Duchacek (1990) defines six mechanisms used by substate actors in the international arena:

1. The establishment of permanent offices in foreign capitals or centres of commerce and industry to represent regional governments.

2. Well-promoted trips by regional leaders, well covered by the media.

3. Short-term, professional fact-finding missions dispatched abroad by regional governments.

4. Trade and investment shows featuring technological, touristic, investment and other advantages of the sub-national unit.

5. Establishment of foreign trade zones. 
6. Participation by representatives of regional governments in international conferences or in the formal diplomatic representation of their national government in foreign capitals.

The instruments that regions and federated units can use internationally are rapidly changing, and are quite diverse and they may include signing treaties and other agreements (political declarations, letters of intent, cooperation agreements, partnerships, etc.), development programmes and assistance, participation in multilateral frameworks, participation in formal and informal networks, public diplomacy (both domestic and international), diasporas etc.

As noted previously, at the start of the $20^{\text {th }}$ century, Quebec and the Basque country had delegations and missions in several world capitals, including London, Paris and Brussels. The creation of offices in major global cities is an appropriate economic strategy for any unit seeking to promote trade and attract investment. It is also an important political and cultural strategy aimed at identity-building and gaining attention in world politics. Blatter et al. (2008) claim the former purpose is more important than the latter. However, this claim is only partially true, as it does not explain why so many European regions and federated units have opened their offices in Brussels.

With the strengthening of the European Union, especially after the Maastricht treaty, Brussels became an increasingly important centre of power and diplomatic activities. Many federated and other sub-national units have started to open up representation offices there. The growth in importance of Brussels coincided with the growth of international activities of sub-national units in the 1990s. Duran (2015) says the creation of the Com- mittee of the Regions in 1994 was an important impetus for federated units and regions to open representation offices in Brussels. But Quebec set up an office in Brussels, long before European regions and federated units began to establish a presence. The mandate of the office covered Belgium, Luxembourg and the Netherlands, and was later extended to cover EU institutions. The city of Birmingham opened an office in 1984, followed by German Länders. In 1988, 15 sub-state units had offices in Brussels and in 1993, it became 54 (Marks, Haesly and Mbaye, 2002). This trend continued to grow throughout the 2000s; by 2002, 160 regions and federated units had offices, and by the end of 2010, this had jumped to over 250 (Kettunen and Kull, 2009). Even though these offices have no formal function in EU decision-making processes, they have a role as designated by their respective regional and federated authorities.

The growing literature on regional offices in Brussels suggests this is an important phenomenon. Brussels is now one of the most important centres of sub-state diplomacy. A permanent presence in Brussels is important not only for those sub-state units that want to take part in European policy, but also for those that want to counterbalance very strong private lobby groups. However, the establishment and maintenance of representation offices is costly not only in Brussels, but in other parts of the world, not all regions and federated units have the necessary resources.

Some federated units and regions, such as Quebec, Flanders, and Wallonia, have several types of offices abroad: economic offices, cultural centres, and general representation offices, which are actually political representations of their respective governments. Others, such as the Republika Srpska, open economic representation offices, which promote trade, attract investment, but also 
deal with political and cultural issues. Representation offices can be operated by the governments of regions and federated units; alternatively, they can be run in cooperation with the private sector or they can be run completely by a contracting organisation or agency (Michelmann, 1990).

Another important instrument frequently used by federated units and regions is the creation of binding and non-binding agreements with states, international organisations and institutions or other regions. Treaty making powers are limited to federated units in a small number of countries, including Austria, Bosnia and Herzegovina, Belgium, Germany and Switzerland. Only Belgium allows its regions and communities to sign international treaties in the areas of their exclusive competence without the consent of the federal authority. In Austria, Bosnia and Herzegovina, Germany and Switzerland, federated units can enter into internationally binding agreements with states only with the consent of their central authorities. In contrast, substate units extensively use cooperation agreements, memoranda of understanding and other forms of agreements of a non-binding nature as a diplomatic tool. Even federated units with treaty-making powers, for example, Belgian regions, have signed significantly more non-binding agreements than treaties. This type of instrument is of interest because it offers more flexibility than the "rigid structure of formal treaties" (Criekemans, 2010: 45).

Regions and federated units striving for international recognition devote significant attention to public diplomacy. Promotion of culture, tourism, education and economy and trade are part of public diplomacy. It is often a rebranding and image building strategy, targeted at a wider general public abroad. Public diplomacy of federated units and regions is rarely seen as a challenge to the sovereignty of their states. As cultural, tourist, educational and other types of campaigns are less likely to be obstructed by central authorities than other diplomatic instruments, public diplomacy is becoming "an increasingly standard component of overall diplomatic practice" (Melissen, 2005: 11). Quebec, Scotland and Catalonia have invested in extensive public diplomacy initiatives, to the point where public diplomacy is institutionalised within their administrations responsible for international relations.

\section{PARTICIPATION IN INTERNATIONAL GOVERNMENTAL ORGANISATIONS AND INSTITUTIONS}

Although membership in international governmental organisations and institutions is almost exclusively reserved for nationstates, federated units and regions attempt to enter the multilateral space in a number of different ways. Some international governmental organisations allow the membership of non-state actors under special conditions and with certain limitations. A case in point is the international governmental organisation la Francophonie, which has allowed the membership of three federated units and regions. Two Canadian provinces are members; Quebec since 1971 and New Brunswick since 1977. Their membership status is the same as the status of 54 state members, but they are presented in the organisation as "participating governments" under the names "Canada-Quebec" and "Canada-Nouveau-Brunswick" respectively. Federation Wallonie-Brussels has been a member of la Francophonie since 1980. Unlike Canada, however, Belgium as a state is not represented in la Francophonie. Other similar examples include the memberships of Åland Islands, 
Faroer Islands and Greenland in the Nordic Council, or Hong Kong (under the name "Hong Kong - China) in the World Trade Organisation (WTO), the World Meteorological Organisation, the International Olympic Committee, the Asian Development Bank etc. Hong Kong's membership in the various organisations was accepted while it was under British rule. For example, it became a member of GATT (General Agreement on Tariffs and Trade) in 1986 and WTO in 1995. It is worth noting that membership in the World Trade Organisation and GATT is not based, as Liu (2009) rightly points out, on statehood, but on special criteria of the WTO and GATT. Article XXVI (5c) of GATT ${ }^{7}$ and Article XII of the Marrakesh Agreement establishing that $\mathrm{WTO}^{8}$ specify that eligibility applies to territories with full autonomy in conducting their external commercial relations.

Memberships of federated units and regions in the above organisations and institutions are still an exception, granted under special circumstances and conditions, and, as such, are often treated as suigeneris. Kincaid argues that for federated units and regions with national aspirations, "representation in international institutions is usually an impor-

7 Article XXVI (5c): "If any of the customs territories, in respect of which a contracting party has accepted this Agreement, possesses or acquires full autonomy in the conduct of its external commercial relations and of the other matters provided for in this Agreement, such territory shall, upon sponsorship through a declaration by the responsible contracting party establishing the above-mentioned fact, be deemed to be a contracting party." General Agreement on Tariffs and Trade (1994)

8 Article XII (1): "Any State or separate customs territory possessing full autonomy in the conduct of its external commercial relations and of the other matters provided for in this Agreement and the Multilateral Trade Agreements may accede to this Agreement, on terms to be agreed between it and the WTO. Such accession shall apply to this Agreement and the Multilateral Trade Agreements annexed thereto," Marrakesh Agreement establishing the WTO tant priority" (Kincaid, 2010: 18). Not all international organisations allow the direct representation of actors who are not states, so federated units and regions use various instruments to establish some sort of cooperation. For example, they may provide technical cooperation, financial contributions and expertise, sign cooperation agreements, and interact directly with the international organisations they are interested in. Quebec, Flanders and Catalonia have used these instruments extensively to establish cooperation with organisations such as UNESCO, WHO, ILO etc. Less developed regions and federated units are usually receivers of technical assistance, financial contributions and expertise from international organisations, providing an opportunity for such sub-states to establish cooperation. The Republika Srps$\mathrm{ka}$, for example, or provinces of South Africa have been on the receiving end of multilateral assistance.

As with other international activities, federated units and regions may aim to participate or have some sort of representation in international organisations and institutions to retain or even increase their autonomy. Only a few international governmental organisations allow sub-state units, federated units and regions to take part in decision-making processes. Although they may not play an active role in policy-making and management, however, their presence and the information they get may help them "mobilise activities at home in order to influence political preference formation within the state" (Blatter et al., 2008: 468).

The direct and indirect participation of federated units and regions in international organisations and institutions may meet with more opposition than bilateral international activities. This opposition may come not only from its own state, but from other 
member states and even the organisation or institution itself.

\section{CONCLUSION}

This Article sets the background for the specificities of the external relations of substate units and seeks a definition able to describe their international activities. Seeking to distinguish the international activities of the smaller units, scholars use words such as paradiplomacy, constituent diplomacy, micro-diplomacy, regional diplomacy etc. This, in turn, leads to ambiguity, controversy, limitations and bias. Therefore, in this Article more neutral terms, notably external relations and international activities have been used.

The Article also analyses the factors behind the development of the international agency of sub-state units. It concludes the increased international presence of federated units and regions cannot be attributed to one factor alone, as some authors argue. Myriad factors, including globalisation, regional trade initiatives such as NAFTA, or regional integration processes such as the EU, nationalism, regionalisation, decentralisation and federalisation, internationalisation of domestic issues etc., have encouraged the international involvement of federated units and regions. Federated units and regions rarely develop international agency for a single reason; several incentives are generally involved, even though some are stronger than others. The external relations of regions and federated units with a distinct identity may be driven by cultural and political motivations, but an economic dimension is usually present as well.

This Article considers how federated units and regions become active internationally, what instruments they use, and how their international activities may affect relations with central authorities. They may develop their international agency in such a way that it is either cooperative or conflictual vis-àvis central state authorities. While conducting external relations, federated units often choose channels other than those of their states, creating their own networks, missions and offices abroad. Federated units consider their international presence a legitimate right derived from a constitutionally given autonomy. Whether motivated by economy, culture or political issues, federated units conduct external relations with the aim of protecting or expanding their autonomy in these domains.

The external relations of federated units and regions do not transform the states in question, as Keating (1999) rightly points, but they do have an effect, albeit limited, on the autonomy of the units and regions. So it is not surprising that reactions from the states are rarely favourable especially when external relations are being pursued by a federated unit with an identity different from the rest of the federation or with a significant presence of nationalism, or if the international activities of the unit are not in line with or contradict the official positions of foreign policy of the federation. Nevertheless, although central authorities may feel threatened by or oppose the external relations of their federated units and regions, the presence of sub-state units on the international scene, as Duchacek rightly claims, is "neither a blessing nor a curse" but "has become a fact of life in an interdependent world” (Duchacek, 1984: 5).

\section{REFERENCES}

Aguirre, I. (1999). Making sense of paradiplomacy? An intertextual enquiry about a concept in search of a definition. In F. Alde- 
coa and M. Keating (Eds.), Paradiplomacy in Action: The Foreign Relation of Sub national Governments (pp. 185-209). London: Frank Cass.

Aldecoa, F. (1999). Towards Plurinational Diplomacy in the Deeper and Wider European Union (1985-2005). In F. Aldecoa and M. Keating (Eds.), Paradiplomacy in Action: The Foreign Relation of Sub national Governments (pp. 82-94). London: Frank Cass.

Atkey, R.G. (1970). The Role of the Provinces in International Affairs. International Journal 26 (1), 249-273.

Balthazar, L. (1999). The Quebec experience: Success or failure? In F. Aldecoa and M. Keating (Eds.), Paradiplomacy in Action: The Foreign Relation of Sub national Governments (pp. 153-169).

Blatter, J., Kreutzer, M., Rentl, M., \&Thiele, J. (2008). The Foreign Relations of European Regions: Competences and Strategies. West European Politics 31 (3), 464-490.

Borzel, T. A. (2000). From Competitive Regionalism to Cooperative Federalism: The Europeanization of the Spanish State of the Autonomies. Publius: The Journal of Federalism 30 (2), 17-42.

Bull, H. (1977). The Anarchical Society. London: MacMillan.

Bullmann, U. (1996). The politics of the third level. Regional \& Federal Studies 6 (2), 3-19.

Butler, R. (1961). Paradiplomacy. In O.S. Arshag (Ed.). Studies in Diplomatic History and Historiography in Honor of G.P. Gooch, (pp. 12-25). London: Longman.
Chaloux, A. \& Paquin, S. (2012). Green Paradiplomacy in North America: Successes and Limits of the NEG-ECP. In H. Bruyninckx, S. Happaerts \& K. Van den Brande (Eds), Sustainable development and subnational governments policy-making and multi-level interactions, (pp. 217-236). Hampshire: Palgrave Macmillan.

Cohen, R. (1998). New Global Diplomacy: Statecraft 2500 BC to 2000 AD. In J. Melissen (Ed.). Innovation in Diplomatic Practice, (1-20), New York: Palgrave.

Cornago, N. (1999). Diplomacy and Paradiplomacy in the Redefinition of International Security: Dimensions of Conflict and Co-operation. In F. Aldecoa and M. Keating (Eds.), Paradiplomacy in Action: The Foreign Relation of Sub national Governments (pp. 40-57). London: Frank Cass.

Cornago, N. (2010). On the Normalization of Sub-State Diplomacy. The Hague Journal of Diplomacy 5(1-2), 11-36.

Cornago, N. (2013) Plural Diplomacies: Normative Predicaments and Functional Imperatives. Leiden: Martinus Nijhoff Publishers.

Criekemans, D. (2010). Regional Sub-State Diplomacy from a Comparative Perspective: Quebec, Scotland, Bavaria, Catalonia, Wallonia and Flanders. The Hague Journal of Diplomacy 5, 37-64.

Duchacek, I. (1984). The International Dimension of Subnational Self-Government.

Publius: The Journal of Federalism 14, 5-31.

Duchacek, I. (1990). Perforated Sovereignties: Towards a Typology of New Actors in Inter- 
national Relations. In H. J. Michelmann \& P. Soldatos (Eds.). Federalism and International Relations: The Role of Subnational Units (pp.133). Oxford: Clarendon Press.

Duran, M. (2015). Mediterranean Paradiplomacies: The Dynamics of Diplomatic Reterritorialization. Leiden: Koninklijke Brill NV.

Feldman, E. J. \& Feldman, L. G. (1984). The Impact of Federalism on the Organization of Canadian Foreign Policy. Publius: The Journal of Federalism 14, 33- 59.

Feldman, E. J. \& Feldman, L. G. (1990). Canada. In H. J. Michelmann \& P. Soldatos (Eds.). Federalism and International Relations: The Role of Subnational Units (pp. 176-210). Oxford: Clarendon Press.

Fry, E. H. (1990a). The United States of America. In H. J. Michelmann \& P. Soldatos (Eds.). Federalism and International Relations: The Role of Subnational Units (pp.276-298). Oxford: Clarendon Press.

Fry, E. H. (1990b). State and Local Governments in the International Arena. Annals of the American Academy of Political Science 509, 118-127.

Habegger, B. (2003). Participation of Sub-national Units in the Foreign Policy of the Federation. In R.Blindenbacher \& A. Koller (Eds.) Federalism in a Changing World, Learning from each other (pp. 159-168). Montreal and Kingston: McGill-Queen's University Press.

Happaerts, S. (2012). Are you Talking to us? How Subnational Governments Respond to Global Sustainable Development Governance. Environmental Policy and Governance $22,127-142$.
Hocking, B. (1993). Localizing Foreign Policy: Non-Central Governments and Mutilayered Diplomacy. London and New York: Macmillan and St Martin's Press.

Kaiser, R. (2005). Substate Governments in International Arenas. Paradiplomacy and Multi-level Governance in Europe and North America. In G. Lachapelle \& S. Paquine (Eds.). Mastering Globalization. New Sub-States' Governance and Strategies, (pp. 90-103). London: Routledge.

Keating, M. (1999). Regions and International Affairs: Motives, Opportunities and Strategies.” In F. Aldecoa and M. Keating (Eds.), Paradiplomacy in Action: The Foreign Relation of Sub national Governments (pp. 1-16). London: Frank Cass.

Keating, M. (2000). The minority nations of Spain and European integration: a new framework for autonomy, Journal of Spanish Cultural Studies 1 (1), 29-42.

Kerremans, B. \& Beyers, J. (1996). The Belgian Sub-national Entities in the European Union: Second or Third Level Players? Regional and Federal Studies 6 (2), 41-55.

Kettunen, P. and Kull, M. (2009). Governing Europe: the Status and Networking Strategies of Finnish, Estonian and German Sub national Offices in Brussels. Regional and Federal Studies 19 (1), 117-142.

Kincaid, J. (1990). Constituent Diplomacy in Federal Polities and the Nationstate: Conflict and Cooperation. In H. J. Michelmann \& P. Soldatos (Eds.). Federalism and International Relations: The Role of Subnational Units (pp. 54-75). Oxford: Clarendon Press. 
Kincaid, J. (2003). Foreign Relations of Sub-national Units, Constituent Diplomacy in Federal Systems, Scientific Background: Subtheme Papers. In R. Blindenbacher \& A. Koller (Eds.) Federalism in Changing World, Learning from each other (pp. 74-96). Montreal and Kingston: McGill-Queen's University Press.

Kincaid, J. (2010). Comparative Observations on the International Activities of Constituent Governments. In F. Requejo (Ed.). Foreign Policy of Constituent Units at the Beginning of 21st Century, (pp.15-28). Barcelona: Collecció Institut d"Estudis Autonòmics.

Langhorne, R. (2005). The Diplomacy of NonState Actors. Diplomacy and Statecraft 16 (2), 331-339.

Lecours, A. (2002a). When Regions Go Abroad: Globalization, Nationalism and Federalism. Conference Paper, Queen's University.

Lecours, A. (2002b). Paradiplomacy: Reflections on the Foreign Policy and International Relations of Regions. International Negotiation 7, 91-114.

Lecours, A. \& Moreno, L. (2001). Paradiplomacy and stateless nations: a reference to the Basque Country. Working Paper 01/06, Unidad de Políticas Comparadas CSIC.

Loughlin, J. (1996). Representing Regions in Europe: The Committee of the Regions. Regional and Federal Studies 6 (2), 146-165.

Loughlin, J. (2000). Regional Autonomy and State Paradigm Shifts in Western Europe. Regional and Federal Studies 10 (2), 10-34.
Marks, G., Haesly, R. \& Mbaye, H. A. D. (2002). What Do Sub national Offices Think They Are Doing in Brussels? Regional and Federal Studies 12 (3), 1-23.

Melissen, J. (1998). Introduction. In J. Melissen (Ed.). Innovation in Diplomatic Practice (pp. xv-xxiii). New York: Palgrave.

Melissen, J. (2005). The New Public Diplomacy: Between Theory and Practice. In J.Melissen (Ed.). The New Public Diplomacy: Soft Power in International Relation (pp.3-27). New York: Palgrave Macmillan.

Michelmann, H. J. (1990). Conclusion. In H. J. Michelmann \& P. Soldatos (Eds.). Federalism and International Relations: The Role of Subnational Units (pp. 299-316). Oxford: Clarendon Press.

Paquin, S. \&Lachapelle, G. (2005). Why do sub-states and regions practice international relations. In G. Lachapelle \& S. Paquine (Eds.). Mastering Globalization. New SubStates' Governance and Strategies, (pp. 77-89). London: Routledge.

Rosenau, J. N. (1997). Along the DomesticForeign Frontier: Exploring Governance in a Turbulent World. Cambridge: Cambridge University Press. Sykes, O. \& Shaw, D. (2008). Investigating Territorial Positioning by Sub-state Territories in Europe. Regional \& Federal Studies 18 (1), 55-76.

Soldatos, P. (1990). An Explanatory Framework for the Study of Federated States as Foreign-policy Actors. In H. J. Michelmann \& P. Soldatos (Eds.). Federalism and International Relations: The Role of Subnational Units (pp. 34-53). Oxford: Clarendon Press. 
Tatham, M. (2010). With or Without You? Revisiting Territorial State-bypassing in EU Interest Representation. Journal of European Public Policy 17 (1), 37-41.

Telford, H. (2003). Expanding the Partnership: The Proposed Council of the Federation and the Challenge to Globalisation. A Series of Commentaries on the Council of Federation, Institute of Intergovernmental Relations, Queen's University.

Thürer, D. (2003). Federalism and Foreign Relations. In R. Blindenbacher \& A. Koller (Eds.) Federalism in Changing World, Learning from each other (pp. 26-32). Montreal and Kingston: McGill-Queen's University Press.

Vengroff, R. \& Rich, J. (2006). Foreign Policy by Other Means: Paradiplomacy and the Canadian Provinces. In P. James, N. Michaud \& M.J. O'Reilly (Eds.) Handbook of Canadian Foreign Policy (pp. 105 -132). Oxford: Lexington Books.

Vile, M.J.C. The Structure of American Federalism. London: Oxford University Press, 1961.

Zubiri, A. U. (1999). The International Relations of Basque Nationalism and the First Basque Autonomous Governments. In F. Aldecoa and M. Keating (Eds.), Paradiplomacy in Action: The Foreign Relation of Sub national Governments (pp. 170-184). London: Frank Cass. 


\section{СХВАТАЬЕ СПОЉНИХ ОДНОСА ФЕДЕРАТИВНИХ ЈЕДИНИЦА И РЕГИОНА}

Кључне ријечи:

парадипломатија; дипломатија; суб-државни актери; федерализам; федеративне јединице; региони; међунарони односи; дипломатски алати; национализам; сепаратизам; међународне организације.

\section{Аутор:}

Др Нина Сајић је научни сарадник у Истраживачком центру за анализу конфликта (ЦАРЦ) Факултета за политику и међународне односе Универзитета Кент, Енглеска, Уједиюено Кратьевство.

Коресподенција: nsajic@yahoo.com

Област:

Међународни односи

DOI:

10.5937/politeia0-24348

Датум пријема чланка:

03.10.2019.

Датум прихватања чланка за објављивање:

\section{Резиме}

Овај рад детално истражује главне теме, које су се појавиле у академском изучавағу сполних односа суб-државних ентитета. На почетку, рад истражује дефиниције спољних односа и међународних активности федеративних јединица и региона и даје кратак историјски преглед када и како су се суб-државне јединице појавиле на међународној сиени; другим ријечима, рад разматра основе за нихово међународно присуство и приказује како су промјене у међународним односима сториле простор за нове актере. Рад дале анализира зашто федеративне јединице и региони ступају у спољне односе, уктучујући нихове мотиве, побуде и стратегије. Рад такође истражује улогу национализма и сепаратизма у међународним активностима федеративних јединица и региона. Какве су реакиије централних власти и које мјере могу да подузму против суб-државних јединица такође се разматрају у овом раду. Учешће региона и федеративних јединииа у међународним организаиијама анализирају се такође у овом раду. 
